\title{
Night Fantasies de Elliott Carter: estratégias de aprendizagem e performance
}

\author{
Luciane Cardassi (The Banff Centre, Banff, Canadá) \\ luciane.cardassi@gmail.com
}

\begin{abstract}
Resumo: Este texto é um relato de minha experiência de aprendizagem e performance da obra Night Fantasies de Elliott Carter. Discuto neste artigo os problemas técnico-pianisticos que encontrei e as estratégias de que lancei mão a fim de superar tais dificuldades, além de algumas questões analíticas e históricas da obra e do compositor que julgo importantes para a performance criteriosa desta peça para piano.
\end{abstract}

Palavras-chave: música contemporânea, música para piano, performance, Elliott Carter, Night Fantasies.

\section{Elliott Carter's Night Fantasies: learning and performance strategies}

\begin{abstract}
In this article, I write about my experience of learning and performing Night Fantasies by Elliott Carter. I discuss the technical problems that I found, as well as the strategies that I made use in order to overcome those difficulties. I also bring some analytical and historical questions about the work and the composer that I find important for a rigorous performance of this piano piece

Keywords: contemporary music, piano music, performance, Elliott Carter, Night Fantasies.
\end{abstract}

\section{1 - Introdução}

Este artigo deriva de minha tese de doutorado (CARDASSI, 2004), na qual discorri sobre três peças das mais significativas no repertório para piano da segunda metade do século XX: Klavierstück IX (1961) de Karlheinz Stockhausen, Sequenza IV (1966) de Luciano Berio e Night Fantasies (1980) de Elliott Carter. A minha experiência prática de aprendizagem e performance dessas obras foi o elemento principal desse trabalho, o qual foi complementado pelo estudo da bibliografia sobre o assunto e discussão com colegas pianistas que já haviam se dedicado ao mesmo repertório. Dois artigos, resultado desse trabalho, foram publicados anteriormente na Revista Per Musi (CARDASSI, 2005 e 2006). 0 presente artigo é o terceiro da série e tem como objeto de estudo a obra Night Fantasies do compositor norte-americano Elliott Carter.

0 repertório para piano dos séculos $X X$ e $X X I$ pode ser classificado em categorias tais como impressionista, neoclássica, serial, minimalista e complexista, entre outras. A obra aqui discutida faz parte do grupo de peças modernas complexistas. 0 conceito de complexismo em música é controverso e não deve ser confundido com complexidade. Neste artigo utilizo o termo "complexo" quando me refiro a dificuldades técnicas da peça estudada, e utilizo o termo "complexismo" ao descrever uma categoria da música contemporânea frequentemente associada à música dos compositores Brian Ferneyhough, Chris Dench e Michael Finnissy, mas da qual outros compositores, e certamente esta peça de Elliott Carter, também fazem parte ${ }^{1}$.

Ao abordarmos uma peça tal qual a obra aqui discutida, ela pode nos causar certo estranhamento, já que muitas vezes nos deparamos com elementos técnicos e/ou musicais não tradicionais. Uma fase de pré-leitura se faz necessária, onde procuramos compreender a notação, desvendar os problemas técnicos e definir estratégias para resolvê-los. A escolha de estratégias de aprendizado é fundamental e influirá certamente no resultado dessa fase, ou seja, na performance da obra. Além disso, a complexidade de peças tais como a obra aqui estudada não é gratuita; ao contrário, configura elemento essencial da estesia do compositor. Para o performer, o conhecimento dessa estesia influenciará as suas escolhas de abordagem tanto de aprendizado quanto de performance (REDGATE, 2007, p.142). É na fase de início do aprendizado de obras complexas tais como a Night Fantasies, que este artigo encontra a sua razão de ser, podendo ser uma ferramenta útil aos colegas que estiverem iniciando o aprendizado 
tanto dessa peça para piano quanto de outras que apresentem desafios semelhantes.

Considero fundamental a definição de estratégias de estudo já no início do aprendizado de uma obra musical do repertório contemporâneo. Deve-se subdividir a peça em partes menores, compreendendo tanto o plano arquitetônico geral da obra quanto os detalhes técnicos de cada célula. Deve-se buscar uma estratégia de simplificação do material que, à primeira vista, pode se mostrar intricado em demasia. "O ato de aprender uma peça é primordialmente o de simplificação, enquanto a arte da performance é a de (re)complexificação" (SCHICK, 1994, p.133). Durante essa fase inicial, ritmos complexos devem ser transformados em unidades que possam ser internalizadas, complexidades da forma e textura devem ser subdividas em materiais compreensíveis e "vários tipos de recursos mnemônicos devem ser empregados simplesmente para que o [intérprete] se lembre o que fazer em seguida" (SCHICK, ibid.). Além da subdivisão sugerida por Schick, é necessário estabelecer "imagens" do som desejado através de ensaios mentais. Assim como nos esportes de precisão, onde a visualização contribui para uma melhor performance do atleta, na música devemos fazer uso do mesmo processo cognitivo. Apesar de chamarmos esse processo cognitivo de ensaios mentais, o que implicaria uma separação dos processos físicos intrínsecos à performance do atleta e do músico, essa separação não existe. "De fato, processos mentais - pensamentos, sentimentos e imagens - todos eles originam-se no cérebro e frequentemente envolvem outras partes do corpo, tais como o sistema nervoso autônomo e o sistema hormonal... o processo cognitivo é portanto um processo físico que ocorre no cérebro e sistema nervoso" (MURPHY, 2005, p.128). Assim, ao criarmos uma imagem sonora de um trecho musical, estamos ao mesmo tempo exercitando a nossa capacidade perceptiva e a nossa capacidade física, preparando o corpo para a realização de um trecho musical. A técnica utilizada na busca desse som ideal e as estratégias de aprendizado dependerão de cada músico, de sua experiência e de sua capacidade perceptiva. Entretanto, "sem a conceitualização de uma imagem desejada, não existe imagem alguma; não se pode materializá-la mesmo que sejam boas as intenções. Esta é a razão pela qual não existe substituto para o estudo lento ou 'préestudo'" (SHERMAN, 1996, p.30).

0 presente artigo tem como objetivo a discussão da obra Night Fantasies de Elliott Carter partindo do ponto de vista do intérprete. Mantive uma pergunta constante enquanto elaborava este texto: se um colega pianista quisesse estudar essa obra e me pedisse sugestões sobre como abordá-la, o que eu diria? Que alicerces embasariam minhas respostas? Com esse enfoque, a discussão foi organizada nos seguintes tópicos: justaposição de caracteres contrastantes, linhas melódicas (independência das linhas melódicas e melodias com grandes saltos intervalares), textura, polirritmias e modulação métrica, episódios em primeiro plano e em segundo plano e estrutura harmônica. Em cada tópico serão abordadas questões técnico-pianísticas ou analíticas que considero fundamentais para a execução criteriosa da peça. Incluo sugestões de como superar os desafios encontrados, além de um breve histórico do compositor e da obra.

\section{2 - Elliott Carter}

Elliott Carter nasceu em 11 de dezembro de 1908 em New York City. Apesar de ter demonstrado interesse pela música desde muito jovem, e de ter nascido em uma família próspera, seus pais não o encorajaram a estudar música, pois esperavam que Elliott viesse a ser o líder dos negócios criados pelo seu avô. Ele chegou a ter aulas de piano quando criança, entretanto o foco principal de seus estudos dessa época era o idioma francês. De fato, Carter passou grande parte de sua infância na Europa e aprendeu a falar francês mesmo antes de ser capaz de escrever em inglês. Esse treinamento precoce para línguas foi decisivo para o grande interesse por diversos idiomas e literatura que Carter sempre demonstrou na sua produção musical.

Em 1922 Elliott Carter ingressou na Horace Mann School e começou a se interessar por música nova. Em 1924 ele conheceu Charles Ives, cuja música e idéias exerceram grande influência no desenvolvimento musical de Carter. Em 1926 ingressou na Harvard University, mas o programa de música daquela universidade o frustrou e Carter então transferiu seus estudos universitários para Literatura Inglesa, Grego e Filosofia, e continuou estudando música (piano, oboé e solfejo) na Longy School em Cambridge. Recebeu seu diploma de Mestre em Música pela Harvard University em 1932, sob orientação de Walter Piston e Gustav Holst. Durante os três anos seguintes estudou em Paris com Nadia Boulanger.

Carter retornou a New York City, em 1935. Apesar de ter sido professor em várias universidades, a escola onde ele deu aulas por mais tempo foi a Juilliard School (1964-84). Foi compositor em residência em vários lugares na Europa e nos Estados Unidos, mas a sua residência permanente é em New York City (Manhattan) e em Waccabuc, ao norte de New York City.

Elliott Carter tem sido um dos mais criativos e influentes compositores por mais de sete décadas. Sua música é freqüentemente caracterizada pelas experimentações com textura e com relações temporais. A Sonata para Piano (1945-46) é a primeira obra de Carter a revelar elementos que viriam mais tarde a alicerçar seu estilo:

Aqui, pela primeira vez, Carter deriva o material musical a partir da
natureza do instrumento, em particular a amplitude de timbres, a
ressonância e os sons harmônicos, construindo uma obra com um
plano arquitetônico no qual contrastam tempos muito lentos e mui-
to rápidos, e do qual uma continuidade de sons de caráter improvi-
satório emergem de um alicerce rigoroso. Nesta peça, Carter revela
pela primeira vez a amplitude da dramaticidade que veio a caracte-
rizar muitas das suas composições posteriores (SCHIFF, 2001, p.202)

Na sua Sonata para Violoncelo (1948) Carter abandonou o neoclassicismo. Nessa obra, violoncelo e piano 
parecem ser completamente independentes ritmicamente. 0 piano toca em rigor metronômico, enquanto o violoncelo toca de uma maneira expressiva, com muito rubato. Essas inovações rítmicas, somadas às harmonias também inovadoras e às frases muito expressivas, proporcionaram um fôlego novo à obra de Carter daquele período. Em entrevista recente, o compositor afirmou que um dos primeiros aspectos que mais lhe chamou atenção na música da primeira metade do século XX foi o pouco interesse dos compositores pelo parâmetro ritmo.

Stravinsky foi talvez um dos que mais experimentou, mas apenas em certas obras como a Sagração da Primavera. Schoenberg também havia procurado elaborar ritmos, já que buscava fazer música como a fala. Sua música tinha ritmos irregulares da mesma maneira como quando falamos usamos ritmos irregulares. Senti então que eu gostaria de encontrar um caminho para desenvolver o lado rítmico da música mais do que outros haviam feito (BAKER, 2002).

Em 1961 o compositor escreveu o Double Concerto para cravo e piano, o qual extrapola as relações rítmicas iniciadas com a Sonata para Violoncelo. De fato, a partir de então, a manipulação do tempo tem sido um dos elementos mais enaltecidos em sua obra.

A tentativa de escapar de uma sensação de tempo mecânica, simples e unidimensional tem sido uma das caracteristicas mais radicais da técnica de Elliott, assim como a maneira com que ele procura derivar e dar forma a todo o material melódico a partir da sonoridade dos diferentes instrumentos (ROSEN, 2007).

Prestes a comemorar os seus 101 anos, Elliott Carter tem tido uma produção musical extraordinária nos últimos anos. A estréia recente ${ }^{2}$ de sua única ópera atesta a personalidade incansável do compositor. 0 título da ópera, What Next?, nos deixa curiosos. Afinal, que surpresas ainda nos reserva Elliott Carter, um dos mais respeitados compositores norte-americanos da atualidade?

\section{3 - Night Fantasies}

Em 1980, Elliott Carter compôs Night Fantasies para piano solo. A peça foi encomendada por quatro pianistas: Paul Jacobs, Gilbert Kalish, Ursula Oppens e Charles Rosen. ${ }^{3}$ Esta obra apresenta um universo de caracteres contrastantes e de grande intensidade dramática, o uso de acordes de todos os intervalos e uma superposição de ritmos criados a partir de uma organização subliminar em polirritmias. É uma obra desafiadora ao extremo, que exige conhecimento profundo do instrumento.

Night Fantasies é uma peça de quase meia-hora em um movimento único. Os seus muitos desafios técnicos serão discutidos a seguir. Apesar da escrita detalhada e rigorosa, a peça oferece espaço para a individualidade dos pianistas.

As mudanças imprevisiveis e os gestos deliberadamente ambíguos são os elementos essenciais do seu universo poético musical - e são também a resposta criativa de Carter a essa comissão. Night Fantasies, na sua sucessão de visões fugitivas, cria um ambiente musical que amplia todas as minúsculas facetas da personalidade de cada intérprete. A música não é uma imagem dos intérpretes, mas foi composta de tal maneira que cada interpretação seja um auto-retrato (SCHIFF, 1983, p.213).
Durante os meses que passei estudando a peça, foi-me de grande ajuda a leitura dos artigos escritos pelo compositor, em particular aqueles escritos no mesmo período da composição da peça. Foi através dessa leitura que vim saber do seu interesse pela literatura, "especialmente a literatura que confronta a natureza do tempo, e a preocupação com o tempo em si. De fato, a sua coleção de textos traz como último artigo o 'Música e a Cortina do Tempo', de 1976" (WARBURTON, 1990, p.209).

Além do interesse pela questão do tempo, Carter também demonstra preocupação com o processo narrativo em literatura. Parece que sua preocupação com o tempo encontrou um correlato literário na busca de Hans Castorp pelo pensamento temporal significativo no romance $A$ Montanha Mágica de Thomas Mann. De fato, em entrevistas a Allen Edwards entre 1968 e 1970, Carter revelou interesse particular pela obra de James Joyce, especialmente pela técnica de epifanias ${ }^{4}$ encontrada, por exemplo, nos Dublinenses. Como o relacionamento entre música e literatura tem sido assunto de grande interesse nos meus trabalhos de pesquisa anteriores, fiquei entusiasmada ao descobrir a expressão "desenvolvimento epifânico" usada por SCHIFF (1983) para descrever os processos compositivos encontrados na obra de Carter. Meu entendimento das Night Fantasies alcançou níveis mais profundos através desse paralelo com a literatura enquanto procurava desenvolver estratégias para aprimorar meu processo de aprendizado da música.

Discuto a seguir as questões técnico-pianísticas ou analíticas que considero essenciais para o aprendizado criterioso dessa obra de Elliott Carter e as estratégias de que lancei mão a fim de superar os desafios encontrados.

\section{1 - Justaposição de caracteres contrastantes} Um dos principais desafios que encontrei ao estudar as Night Fantasies foi justamente o aspecto que mais me chamou a atenção quando a escutei pela primeira vez: a justaposição de caracteres contrastantes. Carter afirma que

\footnotetext{
Night Fantasies é uma peça para piano com caracteres em contínua transformação, sugerindo os pensamentos e sentimentos fugazes que nos vêm à mente durante um periodo de insônia noturna. A evocação sutil, como um noturno, que inicia a peça e que retorna ocasionalmente, é subitamente interrompida por uma série de frases curtas e rápidas que vêm e vão. Esse episódio é seguido por muitos outros de caracteres contrastantes de diferentes durações: algumas vezes são abruptos e outras vezes são desenvolvidos de maneira sutil a partir do que aconteceu antes. A obra culmina na repetição periódica, intensa e obsessiva de um acorde enfático, o qual, ao se desfazer, traz a peça ao seu final.
}

Procurei capturar, nesta peça, a qualidade extravagante e cambiável de nossa vida interior em momentos em que ela não se encontra dominada por intenções e desejos direcionados e fortes - capturar o temperamento poético que, em um contexto romântico, aprecio nas obras de Robert Schumann como Kreisleriana, Carnaval, and Davidsbündlertänze (CARTER, 1982, prefácio à partitura).

Sendo eu também uma apreciadora da obra de Schumann, compreendi as palavras de Carter imediatamente. Entretanto, tocar a sua música com exatidão, e ao mes- 
mo tempo alcançar o nível profundo de interpretação dos caracteres poéticos me parecia tarefa quase impossivel. Era evidente que eu ainda precisava percorrer um longo caminho antes de conseguir expressar a intenção poética do compositor através da minha execução. Optei por aprender a peça dividindo-a em passagens curtas, com o objetivo de nunca perder o conteúdo musical de vista, mesmo que o processo fosse lento. Mantendo esse objetivo maior durante o aprendizado da peça, pude vislumbrar, mesmo que por instantes muito breves, a intenção poética e musical de Carter, o que funcionou para mim como uma recompensa pelo trabalho árduo.

Por exemplo, nas primeiras páginas, as quais considero das mais difíceis devido a mudanças constantes de caráter (e às muitas modulações métricas, assunto que estarei discutindo adiante), procurei aprender a música no andamento sugerido pelo compositor, trabalhando no contraste de caracteres, e nas muitas indicações de articulação, dinâmica e fraseado. A cada página existem muitos detalhes e poderíamos ser tentados a deixar alguns de lado, para serem incorporados posteriormente. Meu enfoque foi sempre incorporar o máximo de informação possível já no aprendizado inicial. Essa estratégia me deu a confiança de que estava fazendo música em cada passagem, por mais curta que fosse, e não apenas superando dificuldades técnicas. Esse processo lento e cuidadoso significou meses de trabalho árduo, mas também a certeza de que ao chegar à última página eu teria construído a minha interpretação da Night Fantasies de maneira mais acurada possivel.

A primeira mudança crucial de caráter acontece logo no início da peça (Ex.1). Os dois últimos tempos do compasso 14 antecipam o novo andamento e caráter. A nova seção - Fantastico - é bastante ativa em termos de contrastes extremos e esse aspecto gera em si grande desafio ao pianista. Essa seção é leggerissimo, com sons de intensidade reduzida e apenas alguns instantes em crescendo para mezzo forte. Devido à grande atividade rítmica e melódica, é difícil manter 0 nível geral de intensidade reduzida indicado pelo compositor. De fato, este é um dos desafios da peça como

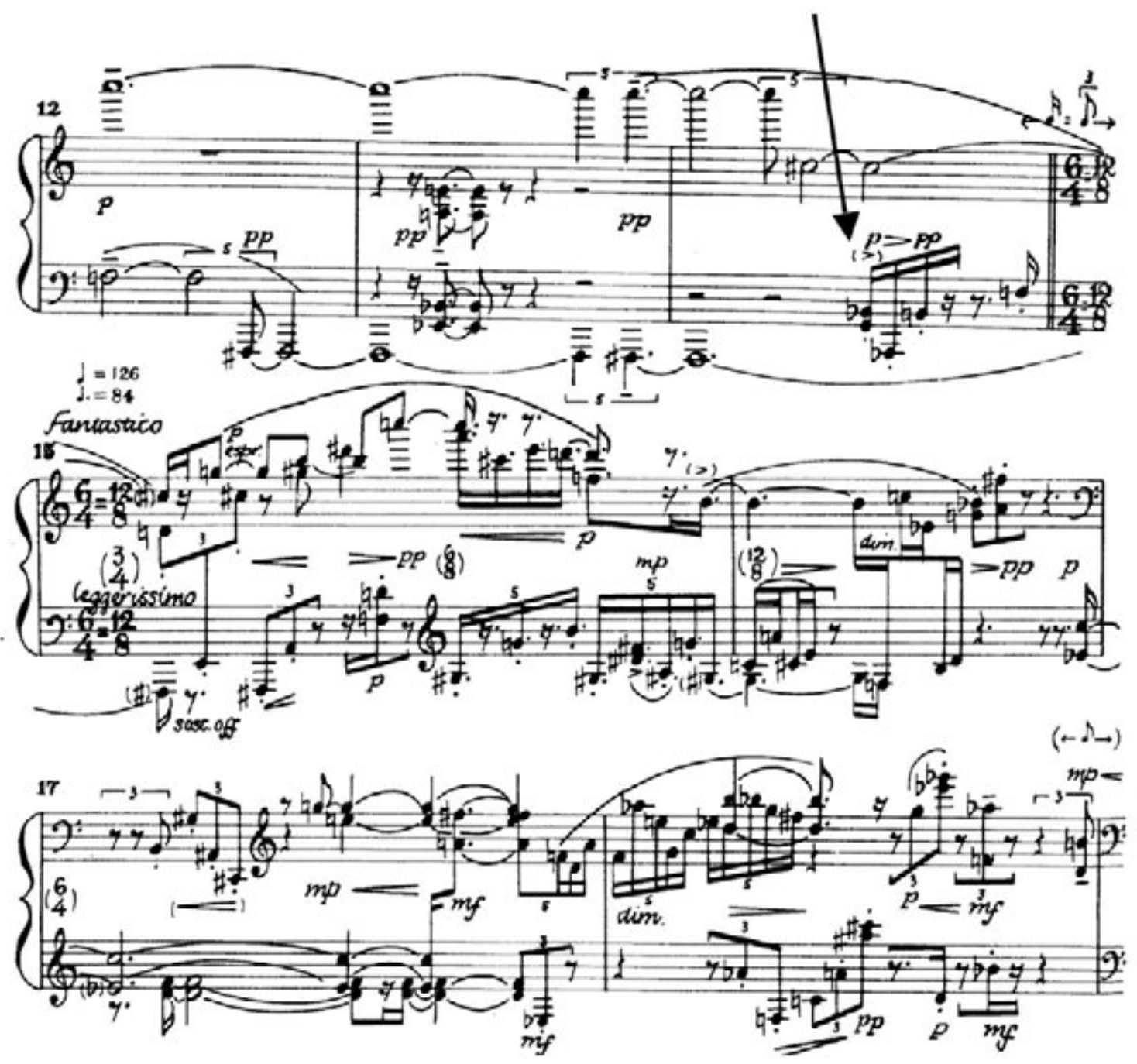

Ex.1 - Night Fantasies - primeira justaposição de caracteres contrastantes: Tranquillo (aqui somente os compassos 13 e 14) e Fantastico (c.15-18). A seta aponta para a primeira modulação métrica, com o novo andamento das semicolcheias. 
um todo - retornar a sons de intensidade reduzida após passagens intensas. Foi-me útil pensar que depois de cada passagem em sons intensos eu precisaria descansar mentalmente, reduzir o peso do meu toque e conseqüentemente guardar energia para ao acordes intensos que viriam ao final da peça.

Além da justaposição de caracteres contrastantes em seções longas como no Ex.1, o contraste ocorre também em escala muito menor, como interrupções breves em diferentes níveis de intensidade e articulação.

\section{2 - Linhas melódicas}

\subsection{1 - Independência das linhas mélodicas}

Por toda a Night Fantasies encontram-se gestos de duas linhas melódicas independentes, compartilhando o mesmo caráter declamatório, porém ocorrendo em contextos musicais diferentes. Procurei estudar essas passagens da mesma maneira: por exemplo, o gesto declamatório dos compassos 59-62 (Ex.2) e a passagem em molto espressivo em polirritmia $8 \times 5$ dos compassos 167-172 (Ex.3). Enquanto estudava esses trechos procurei repetir cada linha melódica em separado, freqüentemente com o auxílio do metrônomo, até que eu obtivesse a independência necessária de cada linha. Só então passei a executar as duas linhas concomitantemente, buscando sempre a realização precisa das polirritmias.

Utilizei a mesma estratégia de aprendizado na seção a seguir, a qual oferece um desafio a mais: as duas linhas melódicas se sobrepõem em um mesmo registro e apresentam uma aceleração em sentido oposto - a mão esquerda mantém um tempo constante enquanto a mão direita passa de quintinas para tercinas (Ex.4). 0 som almejado para essa passagem, com as duas linhas melódicas se aproximando e se afastando, requer enorme precisão de ataques e total independência rítmica.

\subsection{2 - Melodias com grandes saltos intervalares}

Night Fantasies é repleta de escrita melódica, entretanto "a obra não apresenta temas no sentido tradicional e as linhas melódicas, depois de uma primeira aparição, nunca retornam" (ANDERSON, 1988, p.136). As melodias ocorrem freqüentemente com grandes saltos intervalares, visitando diferentes registros do instrumento, o que configura um desafio ao pianista. Conectar notas em registros diferentes requer o uso do pedal de sustentação, já que a maioria desses intervalos não pode ser alcançada através da simples extensão da mão. Entretanto, ao usar o pedal corre-se o risco de sustentar notas outras que aquelas que fazem parte do intervalo a ser conectado. Acredito que o único caminho para uma execução precisa de tais passagens seja através do uso econômico do pedal, somado a uma rápida preparação das próximas notas a serem tocadas. Além disso, o uso cuidadoso de variações de dinâmica para enfatizar as inflexões melódicas que são de difícil percepção em saltos intervalares dessa natureza, e finalmente, a memorização da linha melódica a fim de que se possa manter contato visual com o teclado ao invés da partitura. Melodias com grandes saltos intervalares ocorrem freqüentemente em Night Fantasies, algumas vezes sem acompanhamento, outras vezes com acordes de 3 notas em outra camada de textura, como nos compassos 304-307, ou com acordes de 5 notas como na passagem em quase recitativo nos compassos 377-386 (Ex.5).

As linhas melódicas em Night Fantasies passam às vezes de uma mão para outra, como se pode observar na seção com indicação sempre ben in fuori, cantando (Ex.6). Elas também podem ser encontradas em interrupções bastante breves, como nos compassos 23 e 24 . Independentemente da extensão da melodia, ela sempre guarda semelhança com a música romântica: o caráter cantabile inspirado pelas melodias para voz, como um noturno de Chopin.

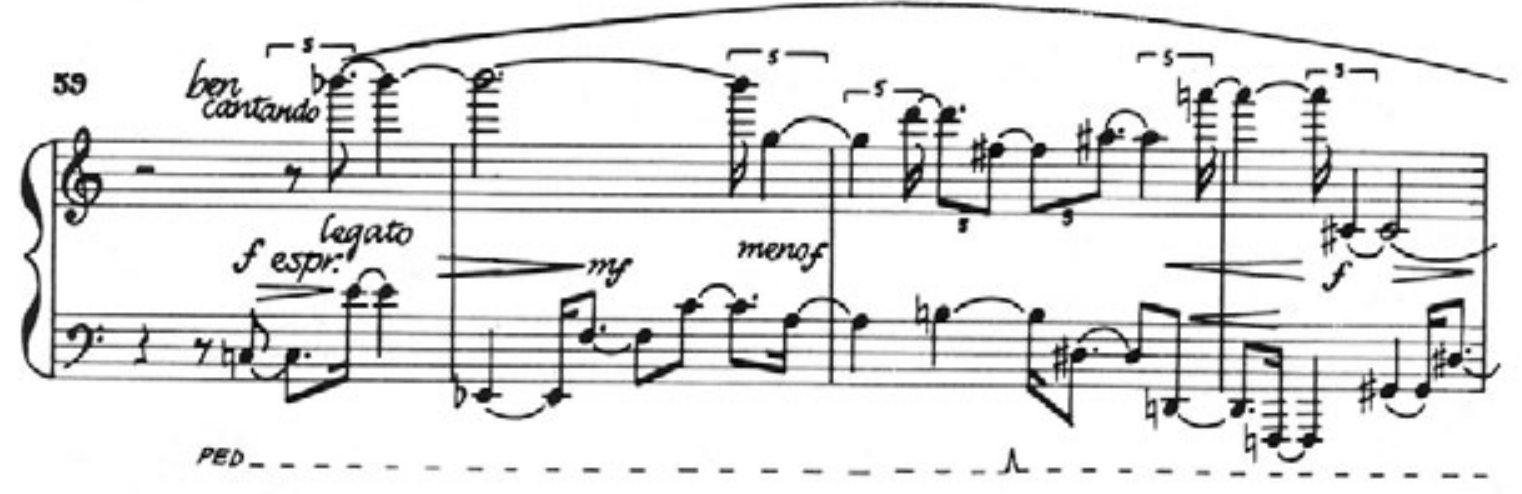

Ex.2 - Night Fantasies - gesto declamatório (c.59-62). Os indicativos do caráter declamatório desta passagem são as expressões ben cantando, forte espressivo e legato 

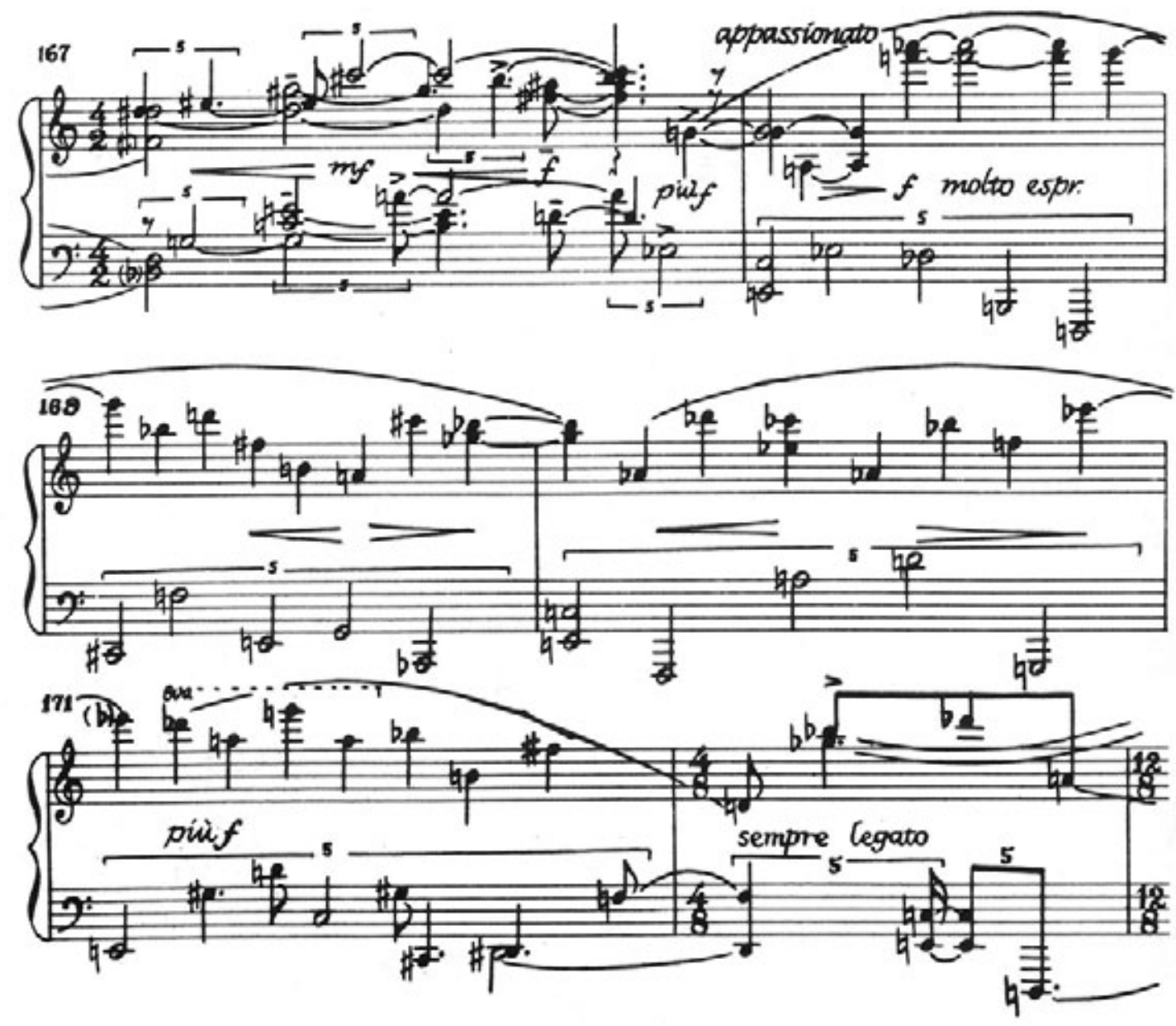

Ex.3 - Night Fantasies - passagem em molto espressivo (c.167-172)
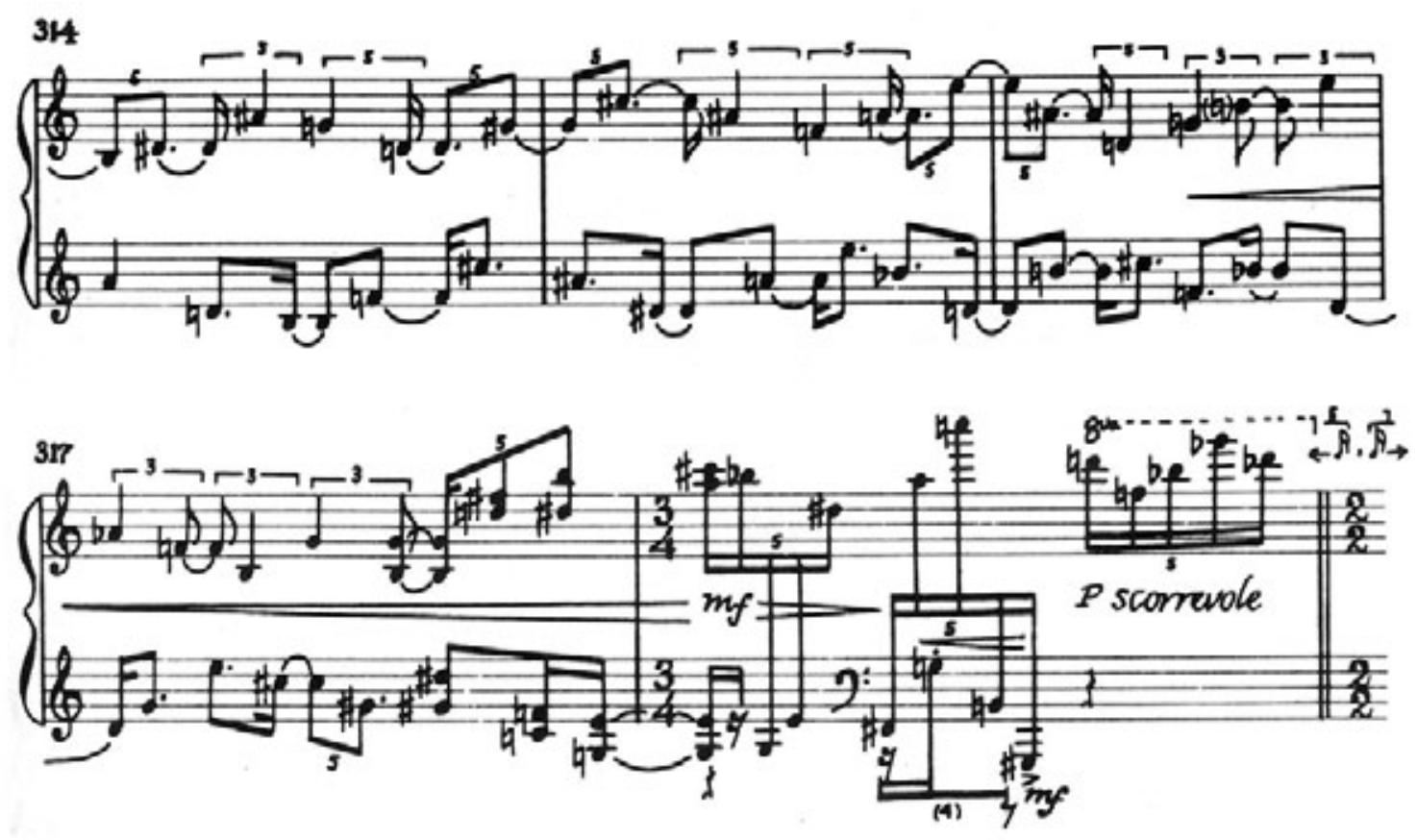

Ex.4 - Night Fantasies - duas linhas melódicas se sobrepondo em registro (c.314-317) 


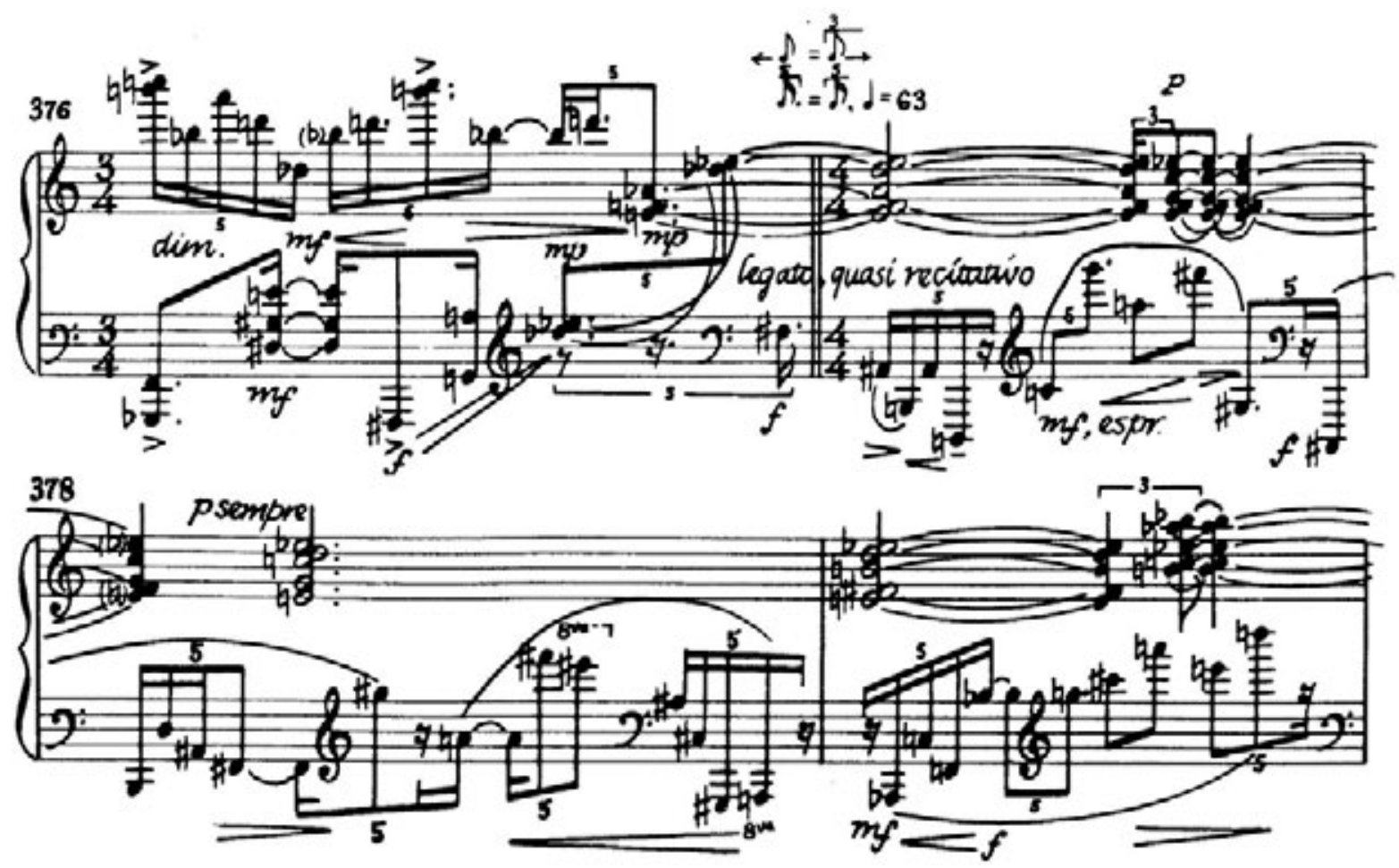

Ex.5 - Night Fantasies - legato, quasi recitativo (c.377 - 379): melodia em grandes saltos intervalares percorrendo diversos registros do piano (mão esquerda), acompanhada por acordes de 5 notas.

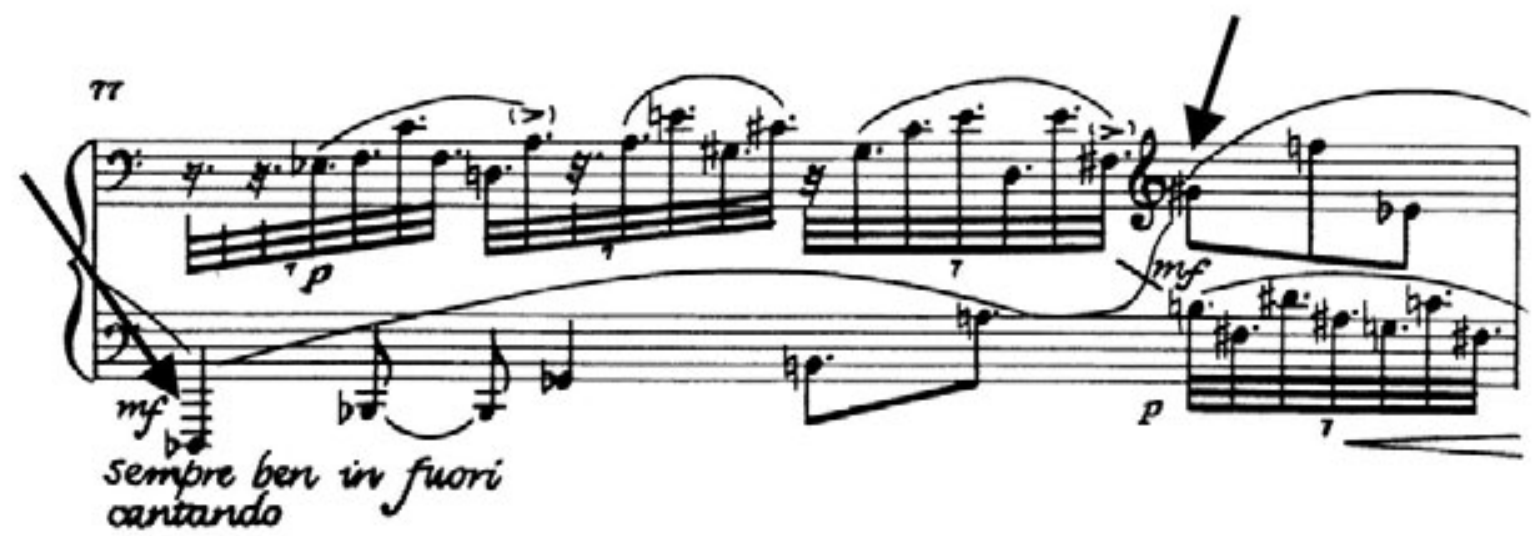

Ex.6 - Night Fantasies - melodia passando de uma mão para outra (c.77)

Contrastando com as melodias com grandes saltos intervalares, Night Fantasies apresenta uma passagem em que a melodia, ou linha expressiva, fica restrita a intervalos de segunda menor (Ex.7). Esse trecho, bastante expressivo, em intensidade reduzida e com uma melodia que se restringe às notas Lá e $\mathrm{Si}$, é altamente contrastante com todas as melodias anteriores da peça. Ele soa como se as melodias de grandes saltos tivessem sido aprisionadas em um intervalo de segunda menor. Embora a passagem possa soar de caráter etéreo para alguns, devido ao uso de intensidades reduzidas e do registro médio-agudo do piano, ou como um "rouxinol mecânico" (SCHIFF, 1983, p.214), percebo esta passagem como um momento de bastante tensão devido às suas restrições: a melodia não chega a lugar algum além das notas Lá e $\mathrm{Si}$, e o uso do pedal é reduzido, o que não permite muita reverberação do instrumento. A extravagância das linhas melódicas com grandes saltos parece estar aprisionada nesse intervalo de segunda menor, pronta para outro arrombo expressivo. A tensão dessa passagem se desfaz quando novas melodias em grandes saltos acontecem 
na seção appassionato dos compassos 168-172 (ver Ex.3 acima). Ao estudar esse trecho, considero essencial uma "compartimentalização" das mãos, especialmente da mão direita, para que as notas Lá e Si da melodia aprisionada não passem desapercebidas, mas ao contrário, que sejam enfatizadas, assim como seu caráter expressivo e tenso.

\section{3 - Textura $^{5}$}

Night Fantasies oferece ao intérprete uma variedade enorme de possibilidades de texturas ao piano. De acordo com SCHIFF (1983, p.214),

\begin{abstract}
o performer é convidado a usar uma variedade enorme de tipos de toque e dinâmica - de leggerissimo a marcatissimo, de staccato a cantabile. A música cobre um espectro do teclado em configurações que se transformam a todo instante, o que leva a uma variação contínua de possibilidades de cores resultantes.
\end{abstract}

Essa transformação exaustiva de níveis de intensidade e de articulação, somada à natureza contrapontística da peça, gera questões técnicas de grande complexidade. Um exemplo do uso de articulações diferentes resultando em desafios ao performer é encontrado na seção recitativo collerico dos compassos 235-240 (Ex.8), onde uma camada de textura cordal em intensidades reduzidas ocorre simultaneamente a uma série de ataques curtos em intensidades elevadas.

Nesse exemplo, ambas as camadas são executadas pelas duas mãos. Já que o uso do pedal poderia comprometer a camada em staccato, o pianista deve buscar uma maneira de sustentar os acordes com os dedos 3 a 5 em ambas as mãos, enquanto a camada em staccato é realizada pelos dedos 1 e 2. Este é um processo elaborado, o de decidir o melhor dedilhado para seções como esta que resulte em uma seção confortável do ponto de vista técnico-pianístico. Momentos como este acontecem por toda a Night Fantasies e cabe ao performer realizar todas as sutilezas de maneira criteriosa.

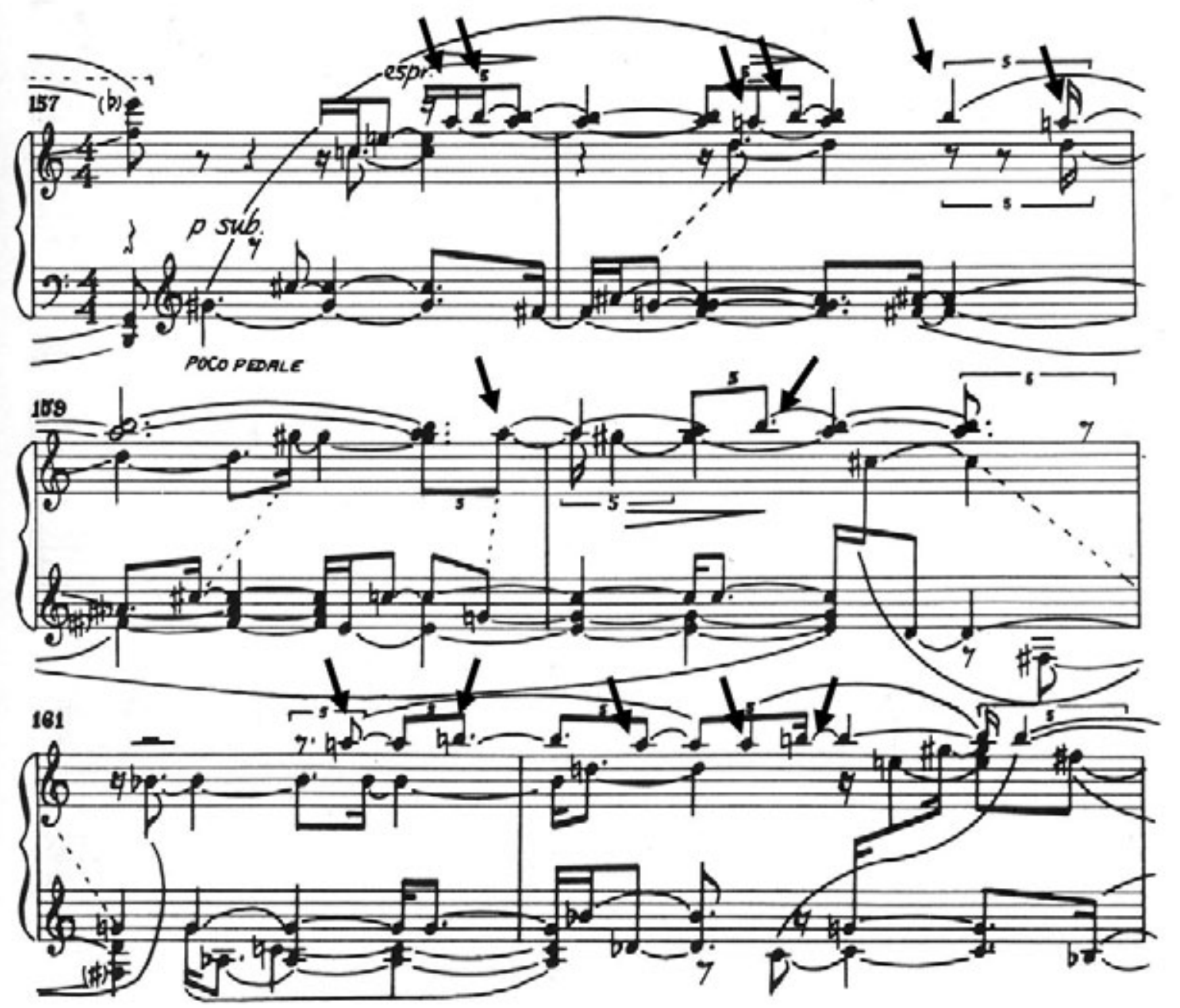

Ex.7 - Night Fantasies - melodia "aprisionada" em um intervalo de segunda menor (c.157-162). As setas indicam os ataques nas notas Lá e Si 

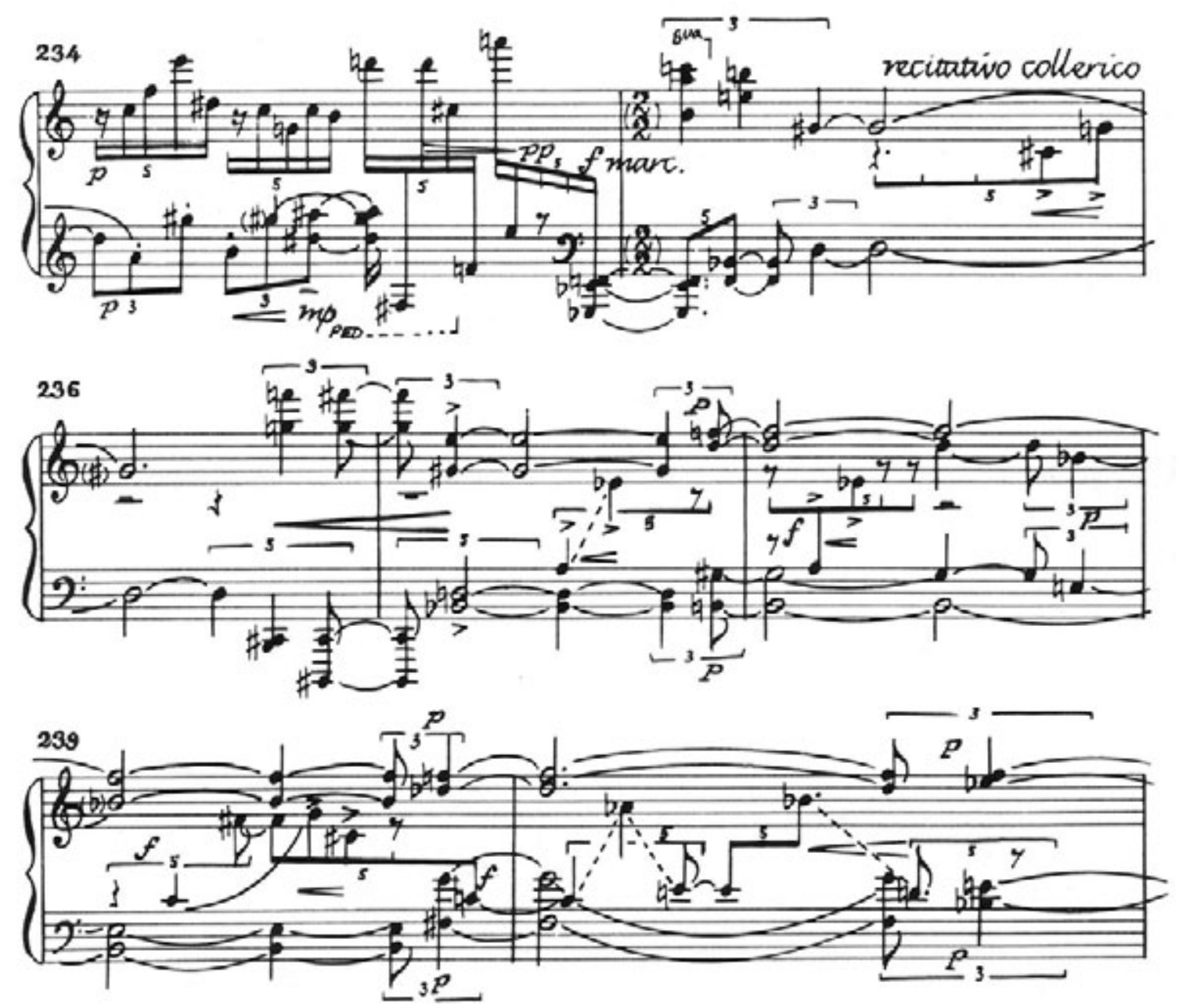

Ex.8 - Night Fantasies - recitativo collerico (c.235-240) - duas camadas: uma em acordes em intensidade piano e a outra em ataques curtos em intensidade forte com acentos

\section{4 - Polirritmias ${ }^{6}$ e modulação métrica ${ }^{7}$}

Polirritmias são, provavelmente, o maior desafio enfrentado pelo pianista ao estudar esta peça de Carter. Night Fantasies foi composta sobre um sistema de pulsos ininterruptos do início ao final: um pulso no tempo de MM 10.8 (um pulso a cada 5 segundos e meio) e outro em MM 8.75 (um pulso a cada 7 segundos), o que forma uma polirritmia subliminar de 216:175. Os dois pulsos somente coincidem no primeiro tempo do compasso $3 \mathrm{e}$ nas últimas notas da peça. Embora não seja aparente ao ouvinte, esta estrutura de polirritmias controla a peça como um todo.

\footnotetext{
0 pulso incansável pode ser comparado a um relógio no quarto de um insone, o seu tic-tac entrando e saindo do nivel consciente do ouvinte. Nunca antes havia Carter inserido sistematicamente um tempo real em uma peça de tais dimensões e com tal rigor, e nunca antes o contraste entre tempo real e tempo psicológico havia sido apresentado de forma mais estrutural que dramática - embora para o insone a visão do relógio possa desencadear sentimentos os mais terriveis e dramáticos (SCHIFF, 1983, p.217).
}

Esta estrutura subliminar, as polirritmias e as muitas modulações métricas que ocorrem por toda Night Fantasies exigem extrema dedicação por parte do intérprete. Mais uma vez, optei por seguir com um estudo em partes. No caso das polirritmias, iniciei com um treinamento rítmico longe do piano, até que eu me sentisse confortável ao executar polirritmias de $3 \times 5$ notas, $7 \times 5$ notas, $5 \times 4$ notas, e assim por diante. Podemos observar no Ex.9 um trecho em polirritmia $5 \times 4$ semicolcheias em andamento rápido e niveis elevados de intensidade com diferentes acentuações. Trechos como esse, freqüentemente em articulação non legato, ocorrem em toda a peça. Se o performer inicia o aprendizado de trechos como esse já com as polirritmias internalizadas, o tempo despendido será certamente reduzido e o nivel de exatidão muito maior.

A fim de solucionar polirritmias com as quais eu não estava familiarizada, utilizei sempre o método do "menor denominador comum", com a subseqüente reescrita da polirritmia (WEISBERG, 1993, p. 18). Adicionar a música às polirritmias pré-estudadas se tornou tarefa factível. Uma outra ferramenta essencial para o aprendizado de polirritmias é o estudo de exercícios progressivos tais 
como aqueles encontrados na Cartilha rítmica para piano do compositor Almeida Prado. ${ }^{8}$ Programas de computador também podem ser úteis na fase de aprendizado de polirritmias. A escuta atenta e repetitiva de um trecho em polirritmia pode auxiliar no aprendizado de passagens de grande dificuldade técnica, entretanto ao escolher esse percurso, sugiro que o performer estude a polirritmia de maneira aprofundada, compreenda as várias camadas individualmente e o ritmo resultante, e só então passe a fazer uso do computador.

No que se refere às modulações métricas, procurei estudar as transições com muita atenção, repetindo-as tantas vezes quanto necessário para que eu começasse a sentir o novo andamento um ou dois tempos antes da transição. Vale a pena ressaltar o fato de que, através das modulações métricas, Carter nos proporciona um guia sobre o novo andamento a ser realizado em cada transição. Por exemplo, nos compassos 14 e 15 (Ex.1 acima), a velocidade das últimas semicolcheias na mão esquerda correspondem à velocidade das tercinas da nova seção. Chega-se a esta conclusão através do seguinte cálculo: se o andamento dessa seção é mínima $=47.25$, ao multiplicarmos esse valor por 8 (número de semicolcheias equivalente à duração de uma míni$\mathrm{ma})$, chegamos à velocidade de cada semicolcheia nesse trecho (47.25 x $8=378)$. Na seção Fantástico, o andamento é semínima $=126$. Logo no primeiro tempo dessa seção ocorrem colcheias em tercinas. A velocidade de cada colcheia em tercina será, portanto, o andamento da unidade de tempo (semínima) multiplicado por 3 $(126 \times 3$ =378). É fundamental o uso de guias tais como este durante as modulações ritmicas em Night Fantasies, a fim de que se possa manter o controle dos muitos andamentos e polirritmias que essa peça oferece.

Outro exemplo de modulação métrica e transições pode ser observado no Ex.10. Neste trecho, a velocidade das semicolcheias nos compassos 318 (em quintinas) e 319 (em septinas) é a mesma, enquanto na próxima transição, o guia para o intérprete está na mão esquerda, pois a velocidade das colcheias se mantém a mesma entre o com- passo 319 e 320 . Mais uma vez o cálculo se faz através da multiplicação do número de ataques em colcheias em cada unidade de tempo, neste caso a mínima. Se mínima =67.5, ao multiplicarmos esse valor por 4 (número de colcheias equivalente a uma mínima), chegamos a 270. Essa é a velocidade de cada ataque em colcheias nessa seção. Para se calcular o andamento da colcheia no compasso 320, teríamos que multiplicar o andamento da unidade de tempo (semínima pontuada $=90$ ) pelo número de colcheias em cada unidade de tempo (3). Portanto, $90 \times 3=270$, exatamente 0 mesmo andamento das colcheias da seção anterior. Apesar desse cálculo não ser necessário nessa transição, já que o próprio compositor deixou explícito na partitura que o andamento das colcheias se mantém o mesmo nessa modulação métrica, é fundamental fazer uso desse tipo de cálculo em muitas das transições em Night Fantasies.

A fundação rítmica da Night Fantasies é uma base rigorosa e imutável sobre a qual flui uma superfície de sons cambiantes. Acredito que essa base rítmica complexa funcione durante a performance como uma salvaguarda, algo que sei está presente, e sabê-lo presente me faz sentir mais segura. Durante a performance as estruturas rítmicas, as polirritmias, as modulações métricas, todo esse emaranhado de complexidades dá lugar ao fluir de gestos de caráter improvisatório, os quais superam a rigidez da estrutura rítmica sobre a qual a peça é construída. A dramaticidade resultante, conseguida depois de superadas as dificuldades técnicas, é um dos aspectos mais fascinantes e intrigantes desta peça para piano.

\section{5 - Episódios em primeiro plano e em segundo plano}

Episódios rápidos e lentos parecem estar continuamente sendo negociados em Night Fantasies, enquanto materiais inicialmente mantidos em segundo plano passam para um primeiro plano e vice-versa. Esse aspecto de mutabilidade contínua constitui um dos elementos essenciais que fazem desta peça monumental de mais de 20 minutos uma experiência auditiva absolutamente fascinante.

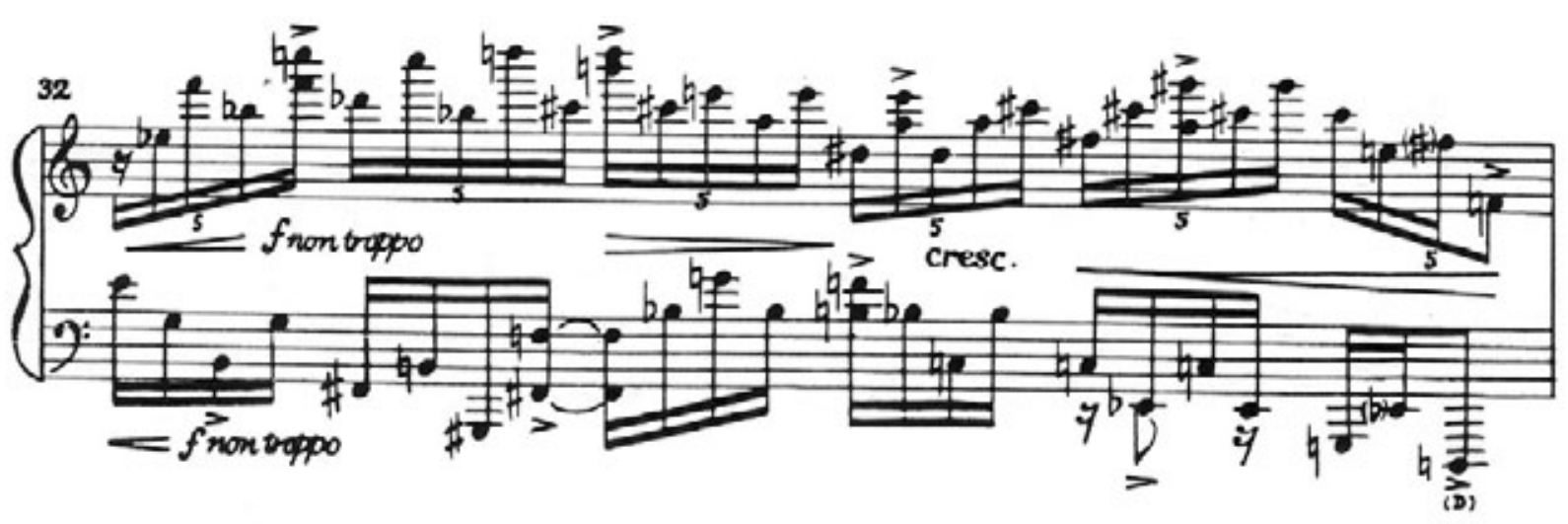

Ex.9 - passagem em polirritmia 5 x 4 e andamento rápido: $\rfloor=94.5$ (c.32) 

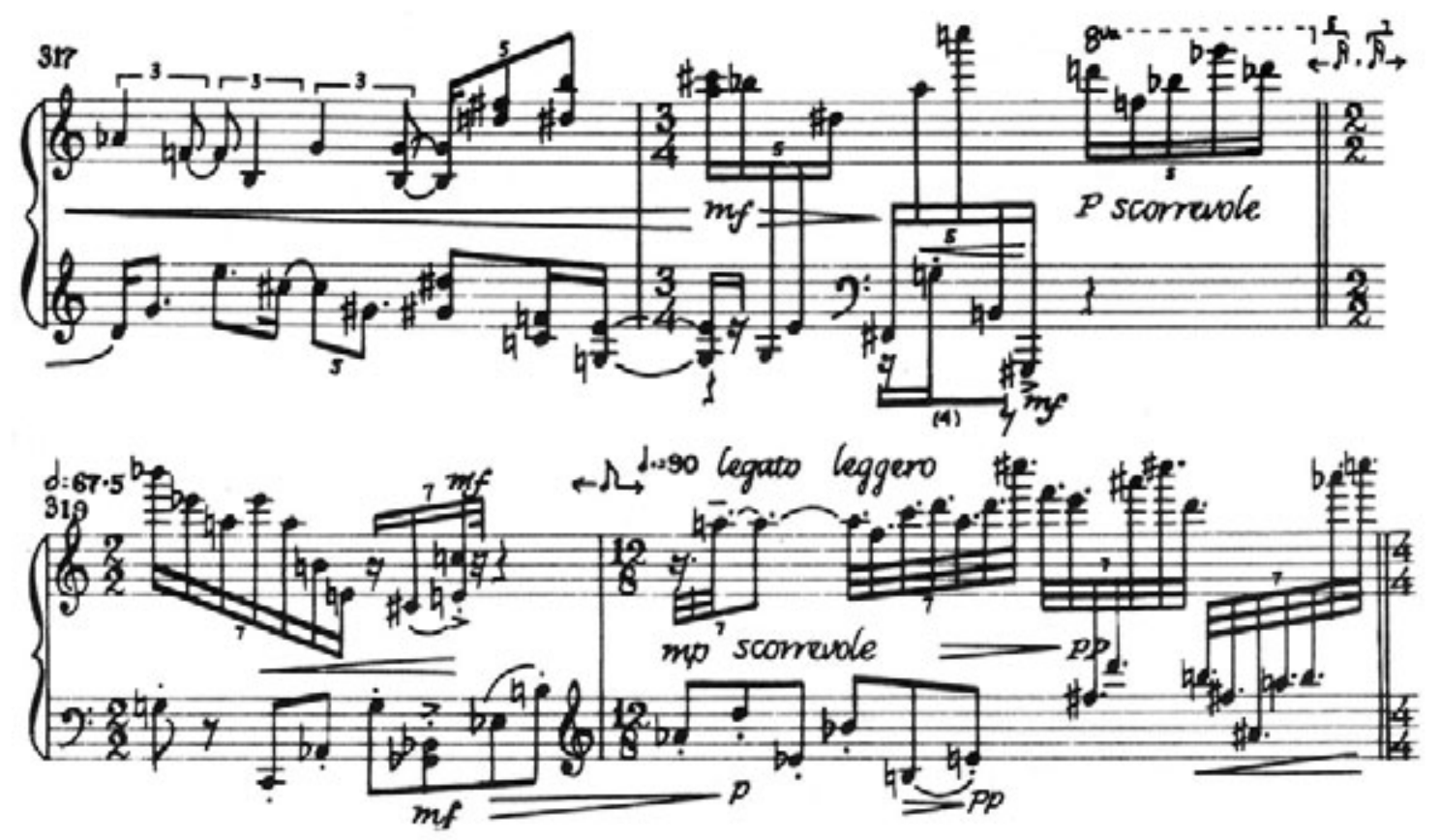

Ex.10 - Night Fantasies - modulações métricas entre c.317 e 318 e entre c.318 e 319

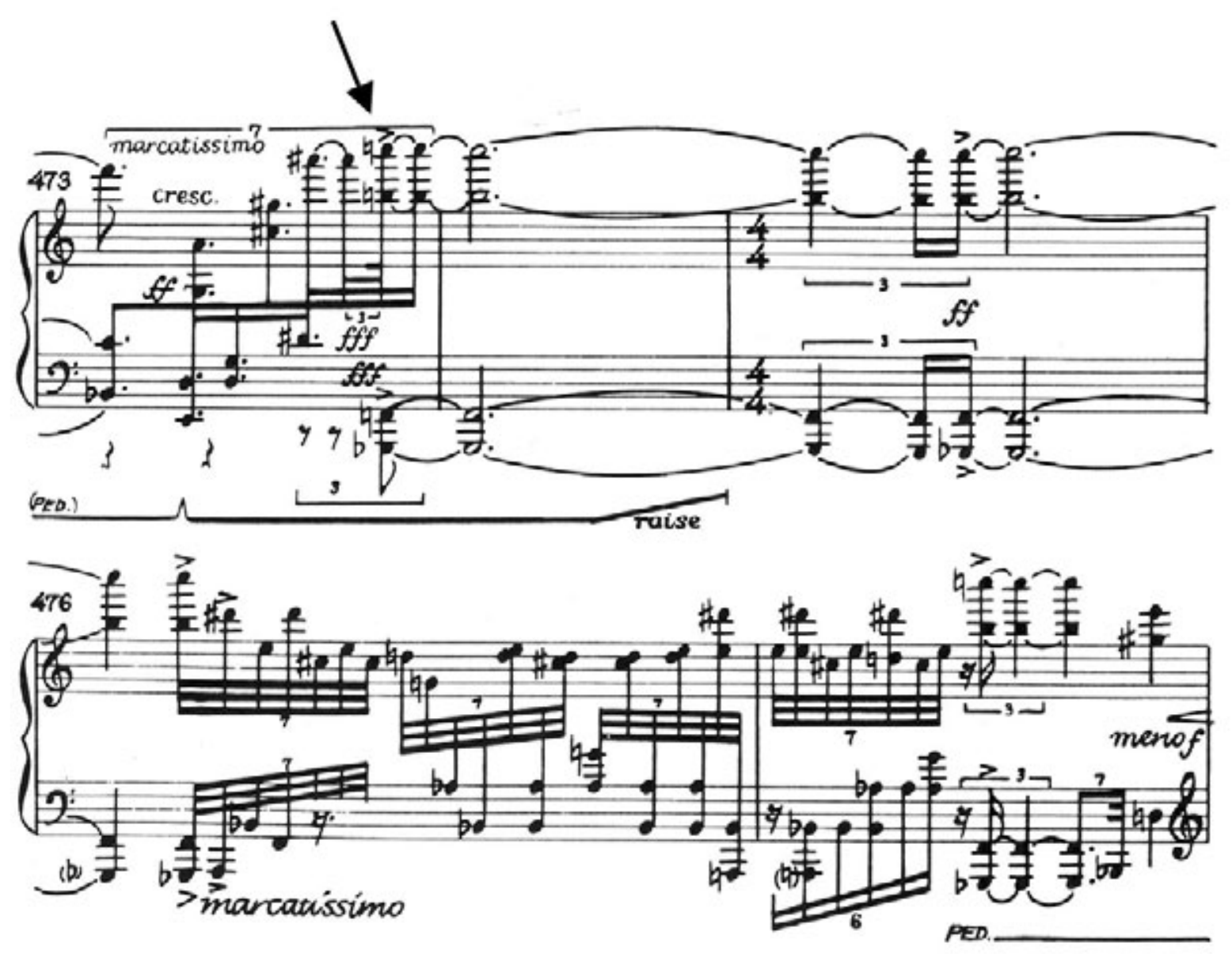

Ex.11 - Night Fantasies - a seta aponta para o primeiro dos acordes repetidos (c.473-477) 
Carter descreve a obra [Night Fantasies] como um movimento rápido interrompido (como em Schumann) por 'trios' lentos que gradualmente se transformam em um movimento lento interrompido por 'trios' rápidos. Episódios rápidos e lentos têm, portanto, suas funções inter-cambiadas de segundo plano para primeiro plano uma diferença que o performer deve evidenciar. Os caracteres de música lenta e rápida também evolvem durante a peça. Vários tipos distintos de música rápida (fantastico, marcato, cantabile, leggero, appassionato) aparecem antes que a seção rápida mais longa da peça aconteça (capriccioso leggerissimo). Todos esses [tipos diferentes de música rápida] retornam como 'trios' durante a segunda parte da peça, com as passagens em marcato se tornando cada vez mais proeminentes. De maneira semelhante, a música lenta tem uma transformação de caráter que vai do início Tranquillo, quase inaudivel, com acordes flutuando e breves ostinatos estáticos, até aparições cada vez mais líricas e intensas (...) Materiais rápidos e lentos finalmente intersectam em seus pontos de maior intensidade com os acordes agressivos dos compasso $472 \mathrm{e}$ subseqüentes; depois desse climax de fusão a música gradualmente se esvai (SCHIFF, 1983, p.217).

Uma execução criteriosa da obra Night Fantasies deve possibilitar ao ouvinte a percepção dessa transferência de materiais do primeiro para o segundo plano e vice-versa, e me perguntei o que eu poderia fazer para evidenciar esse aspecto. Inicialmente procurei enfatizar o contraste entre as passagens rápidas e lentas, no entanto percebi que esse caminho estava colocando em risco os tempos corretos e as modulações métricas que eu havia trabalhado com tanto afinco. Busquei então me concentrar nesse contraste com o cuidado de não exagerar a diferença de andamentos, definidos com precisão pelo compositor. Acredito que cada intérprete, ao executar essa obra, estará em busca constante por precisão técnica, entretanto o caráter único da sua interpretação nunca se perderá. Detalhes interpretativos serão adicionados, sem dúvida, e, por conseguinte, cada intérprete fará da sua interpretação de Night Fantasies o seu próprio auto-retrato sonoro. 0 constante intercâmbio de funções entre as passagens rápidas e lentas produz em Night Fantasies um clímax extraordinário com a repetição de um acorde (Ex.11) na seção final da peça.
Essa repetição de acordes acontece depois de aproximadamente 20 minutos de música incrivelmente complexa e é fundamental que o intérprete maneje apropriadamente sua energia física e mental, pois esses acordes finais são essenciais para uma performance convincente.

\section{6 - Estrutura harmônica}

A estrutura harmônica de Night Fantasies é formada por 88 acordes de 12 notas abrangendo todos os intervalos possiveis. Cada intervalo faz par com seu inverso equivalente ao redor de um trítono central. Em outras palavras, segundas menores fazem par com sétimas maiores, segundas maiores com sétimas menores, terceiras menores com sextas maiores e assim por diante, sempre mantendo um trítono entre eles (Ex.12).

0 compositor faz uso desses 88 acordes de todos os intervalos das maneiras mais variadas. Algumas vezes apenas uma classe de intervalos se manifesta, outras vezes acordes de três notas predominam. Há passagens em que Carter recorre ao seu aparentemente favorito tetracorde $(0,1,4,6) .{ }^{9} 0$ processo compositivo foi, obviamente, muito mais complexo do que apenas escolher alguns intervalos predominantes para cada seção e uma análise desse aspecto vai além dos objetivos deste trabalho. Por outro lado, do ponto de vista do performer, considero importante estar ciente de pelo menos alguns pontos estratégicos nos quais determinados intervalos predominam e como eles são transformados nas passagens que seguem. Por exemplo, foi-me útil saber que intervalos de quarta e quinta predominam no início, enquanto sétimas e nonas ocorrem mais freqüentemente no final da peça, e que na seção central caprichoso que acontece a partir do compasso 195, um acorde de três notas predomina $(0,1,5)$. Acima de tudo, considero importante estar ciente das transformações pelas quais passam os intervalos de uma seção a outra.

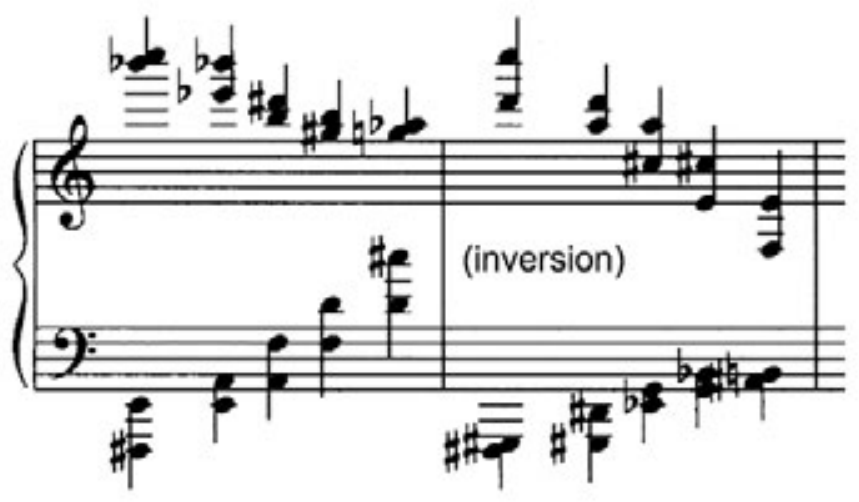

Ex.12 - Night Fantasies - acorde principal entre os 88 acordes de todos os intervalos (SCHIFF, 1983, p.214) 


\section{4 - Comentários finais}

A discussão aqui apresentada é o resultado de minhas reflexões durante e após o aprendizado desta obra monumental de Elliott Carter. Tive que trabalhar exaustivamente em diversas questões técnico-pianísticas, além de desafios rítmicos que eram, de certa forma, novos para mim, e que provavelmente o são para muitos músicos. Considero essencial desenvolver total controle sobre as polirritmias e modulações métricas, assim como absoluta independência das mãos, já que cada linha melódica ocorre freqüentemente com um tipo de articulação, ritmo e níveis de intensidade diferentes. Depois de superadas as dificuldades técnicas, o performer pode focar seu estudo na realização eficaz da justaposição de caracteres contrastantes e no intercâmbio de funções dos episódios em segundo e primeiro plano.

Os detalhes e, conseqüentemente, os desafios que Night Fantasies oferece são muitos. De fato, para Carter, cada detalhe é essencial:

Todo momento deve, de alguma forma, se fazer importante, assim como todo detalhe (...). Estou sempre interessado nas frases de um compositor, no conteúdo e forma dessas frases, na maneira como ele as une, o tipo de articulação que utiliza, assim como no fluxo geral e continuidade de uma seção longa e na construção da obra como um todo (CARTER, 1967).
Existem, sem a menor dúvida, muitos obstáculos técnicos a serem vencidos pelo pianista que se aventura por esta peça, entretanto esses desafios não devem desencorajar o performer interessado nesse repertório. Ao contrário, as dificuldades técnicas devem ser encaradas como ferramentas para o performer aprimorar seu desenvolvimento musical. 0 objetivo deve ser sempre a busca pela performance ideal e que proporcione ao ouvinte uma experiência perceptiva ideal. Enquanto nos preparamos para essa performance ideal, muitos caminhos terão que ser percorridos, e é nessa fase de definição de estratégias de aprendizado que trabalhos como este encontram a sua razão de ser. Questões técnicas discutidas neste artigo podem parecer sobre-humanas para alguns. Prefiro, no entanto, salientar que a peça musical em estudo foi concebida para ser executada por um pianista, não por uma máquina. Deslizes de performance e pequenas imperfeições acontecerão indubitavelmente, e devem ser encarados como oportunidades para criação de uma performance pessoal, diferenciada, única. Apesar dos problemas aqui discutidos terem sido originados na minha experiência prática e as soluções técnicas apresentadas terem, certamente, um enfoque pessoal, espero que este trabalho possa ser útil a outros colegas pianistas que decidam se dedicar ao estudo desta peça de Elliott Carter, uma das mais desafiadoras e fascinantes do repertório para piano do século XX.

\section{Referências Bibliográficas}

ANDERSON, Bruce. The Solo Piano Music of Elliott Carter: A Performance Guide. PhD diss., New York University, 1988.

BAKER, Alan. "An Interview with Elliott Carter". American Public Media, July 2002. Disponivel em <http://musicmavericks.publicradio.org/features/interview_carter.html> Acesso em 10/06/2008.

CARDASSI, Luciane. Contemporary Piano Repertoire: A Performer's Guide To Three Pieces by Stockhausen, Berio and Carter. D.M.A. Dissertation, University of California, San Diego, 2004.

"Klavierstück IX de Karlheinz Stockhausen: estratégias de aprendizagem e performance". Per Musi. n.12, jul-dez. Belo Horizonte: UFMG, 2005, p.55-64.

"Sequenza IV de Luciano Berio: estratégias de aprendizagem e performance". Per Musi. n.14, jul-dez. Belo Horizonte: UFMG, 2006, p.44-56.

CARTER, Elliott. Night Fantasies, for piano. Associated Music Publishers, New York, 1982.

"Shop Talk by an American Composer", in: SCHWARTZ, Elliott \& CHILDS, Barney (eds.), Contemporary Composers on Contemporary Music. Holt, Rinehart and Winston, New York, 1967.

GANDELMAN, Salomea \& COHEN, Sara. Cartilha rítmica para piano de Almeda Prado. Rio de Janeiro, 2006.

MAHNKOPF, Claus-Steffen. "Complex Music: An Attempt at a Definition", in: MAHNKOPF, Claus-Steffen, COX, Frank \& SCHURIG, Wolfram (eds.), Polyphony \& Complexity. Hofheim, Wolke Verlag, 2002. p.54-64.

MURPHY, Shane. "Imagery: Inner Theater Becomes Reality", in: MURPHY, Shane (ed.), The Sport Psych Handbook. Champaign, Human Kinetics, 2005. p. 127-151.

REDGATE, Christopher. "A Discussion of Practices Used in Learning Complex Music with Specific Reference to Roger Redgate's Ausgangspunkte". Contemporary Music Review. vol. 26, part 2, April 2007. p.141-149.

ROSEN, Charles. "An Old Master Still in Development". The New York Times. 09/12/2007.

SADIE, Stanley (ed.). The New Grove Dictionary of Music and Musicians. London, Macmillan Publishers Limited, 2001.

SCHICK, Steven. "Developing an Interpretive Context: Learning Brian Ferneyhough's Bone Alphabet". Perspectives in New Music. Vol. 32, no. 1, Winter, 1994. p.132-153.

SCHIFF, David. The Music of Elliott Carter. New York, Ernst Eulenburg, 1983.

"Elliott Carter". In: SADIE, Stanley (ed.). The New Grove Dictionary of Music and Musicians. London, Macmillan

Publishers Limits, 2001. vol. 25, p.323. 
SHERMAN, Russell. Piano Pieces. New York, Farrar, Straus and Giroux, 1996.

WARBURTON, Thomas. "A Literary Approach to Carter's Night Fantasies", Music Review, Vol. 51; Issue 3, Aug 1990; p.208-220.

WEISBERG, Arthur. Performing Twentieth-Century Music - A Handbook for Conductors and Instrumentalists. New Haven, Yale University Press, 1993.

\section{Notas}

1 A música complexista apresenta 3 elementos principais: grande quantidade de informação, tanto quantitativa: (uma massa de eventos sonoros acontecendo de maneira rápida e densa), quanto qualitativa (uma massa de relações subcutâneas exibindo diferentes dimensões, riqueza semântica e grande habilidade em formar contatos mútuos); polivalência dos níveis de significado e um alto nível de energia de coesão entre as partes e o todo (MAHNKOPF, 2002, p. 54).

2 "What Next", a única ópera de Carter, estreou na Staatsoper Unter den Linden, em Berlim, em 16 de setembro de 1999. A estréia norte-americana aconteceu no Tanglewood Music Centre em Lenox, Massachusetts, em 26 de julho de 2006.

3 Cada um dos quatro pianistas que comissionaram a peça realizou a sua estréia da obra em 1980 e 1981 . Oppens foi a primeira a estrear a peça em 1980 (em Bath, England) e a lançar Night Fantasies em CD, em 1981, tendo revisitado a obra desde então e lançado sua nova versão em 2008. Além de gravações de Oppens, Rosen, Jacobs e Kalish, a obra foi lançada em CD por vários pianistas, incluindo Aleck Karis, Stephen Drury e Pierre-Laurent Aimard.

4 Técnica através da qual uma obra literária apresenta momentos em que a realidade ou o significado profundo de algo é percebido de forma súbita, causado por um acontecimento banal.

5 Textura se refere aos aspectos sonoros de uma estrutura musical. Pode estar relacionado tanto aos aspectos verticais de uma obra ou passagem como, por exemplo, a maneira pela qual as partes individuais ou vozes se inter-relacionam, ou a atributos tais como cor e ritmo, ou ainda a características de performance como articulação e níveis de intensidade. Embora o controle textural tenha sido de grande importância para compositores desde a Idade Média, com o advento do dodecafonismo e do serialismo no século XX e com o subseqüente colapso do sistema tonal na música ocidental, textura passou a ser um elemento ainda mais importante na composição (SADIE, 2001, p. 323).

6 Polirritmia é uma manifestação simultânea de diferentes divisões de uma unidade de tempo, ou de uma duração temporal maior. Com polirritmias simples, tais como 3 contra 2, os pulsos coincidem com freqüência. Carter, no entanto, recorre a polirritmias lentas que raramente coincidem (SCHIFF, 1983, p. 44).

7 Modulação métrica é uma mudança proporcional de tempo que ocorre através da re-escrita de um tempo metronômico como na indicação "nova mínima igual à semínima pontuada anterior". 0 termo modulação métrica foi usado pela primeira vez por Richard Franko Goldman em 1951 ao descrever a Cello Sonata de Carter, mas o compositor tem utilizado esse recurso desde a sua Sinfonia n. 1 de 1942. Em Night Fantasies, modulações métricas ocorrem em toda a peça.

8 A Cartilha rítmica para piano do compositor Almeida Prado (GANDELMAN, 2006) oferece vários exercícios progressivos para o aprendizado de polirritmias. 0 valor artístico e pedagógico destas peças curtas é imenso e recomendo aos alunos de piano e outros instrumentos que se familiarizem com essa obra antes de se aventurarem por obras tais como a discutida neste artigo.

9 Utilizo aqui o conceito de classe de intervalos em que as notas são consideradas sem ordem especifica. Dessa maneira, os 12 intervalos possíveis em uma oitava são reduzidos a um grupo de 7 classes de intervalos numerados de 0 a 6 . Cada classe de intervalos é formada pela menor distância entre duas notas, não importando a ordem delas.

Luciane Cardassi, pianista, é Doutora em Música (Contemporary Piano Performance) pela Universidade da Califórnia, San Diego (EUA) e Mestre em Música pela Universidade Federal do Rio Grande do Sul. Foi bolsista da CAPES. Tem artigos publicados em importantes revistas nacionais na área de performance da música contemporânea, além de palestras e concertos no Brasil e exterior. 